Reprod. Nutr. Dévelop., 1987, 27 (2 B), 491-500.

\title{
Characteristics of growth hormone response to the administration of growth hormone-releasing hormone (GRF) in the lamb
}

\author{
B. BARENTON, M. DUCLOS, J. DIAZ $(*)$, F. DELETANG $\left({ }^{*}\right)$, J.-P. DULOR, \\ M. BLANCHARD, J. CHARRIER
}

Avec la collaboration technique de Véronique GARANDEL et A. FRAYSSE

Station de Physiologie Animale, INRA-ENSA, 34060 Montpellier Cedex, France. (*) SANOFI Recherche, Montpellier.

Summary. Human growth hormone releasing hormone (GRF 1-44 or GRF 1-29) was administered to lambs at two different physiological stages (suckling : 5-6 week-old and weaned : 14-15 week-old) when growth hormone $(\mathrm{GH})$ secretory patterns were different : suckling lambs exhibited flat basal $\mathrm{GH}$ profiles $(5-10 \mathrm{ng} / \mathrm{ml})$ while the weaned lambs had frequent spontaneous episodes of $\mathrm{GH}$ release $(15-65 \mathrm{ng} / \mathrm{ml})$.

The iv injection of GRF evoked an immediate release of $\mathrm{GH}$. In each case, plasma $\mathrm{GH}$ levels reached a maximum 1-4 min after the injection. The secretory spike was multiphasic and lasted 30-60 min. Administration of GRF $(0.1 \mu \mathrm{g} / \mathrm{kg})$ in weaned lambs induced $\mathrm{GH}$ pulses with an amplitude comparable to that of endogenous peaks. The induction of a $\mathrm{GH}$ peak occurred even when a spontaneous peak immediately preceded the GRF injection. Also, spontaneous peaks were observed during the hour following a GRF-induced GH peak.

In sucking lambs, GRF injected intravenously as a single bolus in a range of 0.01 to 05 . $\mu \mathrm{g} / \mathrm{kg}$ ( 2 to $100 \mathrm{pmoles} / \mathrm{kg}$ ) stimulated $\mathrm{GH}$ release in a dose-dependent manner.

Chronic administration of GRF 10.75 nmole GRF 1-44 or GRF 1-29 per kg twice daily for 21 days) in newborn lambs increased significantly $(p<0.001)$ the acute response to GRF during the course of the treatment. GH response to GRF 1-44 and GRF 1-29 was the same.

These data show that lambs are highly responsive to GRF action during both suckling and weaning and suggest that there is no in vivo desensitization of the pituitary gland after acute or chronic GRF administration.

\section{Introduction.}

Since human growth hormone-releasing hormone (hGRF) was characterized and synthesized (Guillemin et al., 1982 ; Rivier et al., 1982), extensive in vivo and in vitro studies have been initiated (Guillemin et al., 1984). Its specificity with respect to growth hormone $(\mathrm{GH})$ secretion is well documented (Wehrenberg et al., 1982 ; Thorner et al., 1983 ; Moseley et al., 1984). Although the amino acid sequence of GRF is species-specific (Ling et al., 1984), GRF of human origin has been demonstrated to be extremely potent in a number of very different species such as rats (Rivier et al., 1982 ; Wehrenberg et al., 1982), ruminants (Hodate et 
al., 1984), pigs (Kraft et al., 1985) and fowl (Scanes et al., 1984). In sheep, hGRF has been shown to stimulate GH secretion in the fetus (Ohmura et al., 1984), as well as in cultured pituitary cells (Law et al., 1984; Blanchard et al., 1987). Therefore hGRF appears to be an appropriate form of the peptide to use to investigate dynamic changes of $\mathrm{GH}$ release in sheep.

Plasma GH levels are very high in the ovine fetus at late gestation, then fall abruptly at birth (Bassett and Alexander, 1971; Gluckman et al., 1979a). However, there is no decrease in absolute or relative pituitary GH content during this period (Charrier, 1973). The infusion of somatostatin into fetal or adult sheep causes, at best, $50 \%$ inhibition of GH release (Davis and Anfinson, 1975; Gluckman et al., 1979b). Thus it is likely that another mechanism is involved in the postnatal decrease in $\mathrm{GH}$ secretion, either a decrease in pituitary sensitivity to GRF action or a decreased stimulation of this gland.

The present series of experiments were designed to study the in vivo responsivity of lambs to GRF. We have also examined for possible desensitization of the pituitary gland in lambs receiving a single dose of GRF or chronic treatment.

\section{Materials and methods.}

All the animals used in this study were Mérinos d'Arles lambs. They were kept inside with their mother until weaning at 7 week of age and under natural conditions of light and temperature. They received food and water ad libitum. The lambs were conditioned to experimental manipulations from the time of birth.

When the blood sampling intervals were every 5 min or longer, the blood was taken by venipuncture into heparinized glass tubes and GRF was injected intravenously. With shorter intervals of time, the blood was collected into heparinized glass tubes through an indwelling catheter placed into the jugular vein two days before. In this case, GRF was injected through a second catheter followed by $1 \mathrm{ml}$ of sterile normal sheep serum (NSS).

For all the acute tests, GRF was administered intravenously (iv). The test time varied except for the chronic treatment regime. During this regime, subcutaneous (sc) injections of GRF were given at 8 am and $8 \mathrm{pm}$ for 21 days and blood samples were drawn beginning at $30 \mathrm{~min}$ prior to the $8 \mathrm{am}$ injection.

Human GRF 1-44 (SR95228) and GRF 1-29 (SR95515) were gifts of SanofiRecherche (Montpellier). The powder was dissolved in sterile saline prior to use. Just before injection, $0.5 \mathrm{ml}$ of the solution was diluted with $0.5 \mathrm{ml}$ of NSS. The vehicle consisted of $1 \mathrm{ml}$ of sterile saline/NSS (1: 1).

Plasma was separated by centrifugation and stored at $-20^{\circ} \mathrm{C}$ until assayed. Ovine $\mathrm{GH}(\mathrm{oGH})$ was measured by specific radioimmunoassay using a double antibody separation method. Reagents for the oGH assay were supplied by the National Hormone and Pituitary Program (NIADDK, Bethesda), except for the second antibody (sheep anti-rabbit-gammaglobulin serum) which was prepared in our lab. The sensitivity of the assay was $0.5 \mathrm{ng} / \mathrm{ml}$ and the intra-assay variation was $5 \%$. All samples from the same experiment were run in the same assay at the appropriate dilution. 


\section{Results.}

Figure 1 shows the typical effect of GRF $1-44(2 \mu \mathrm{g} / \mathrm{kg})$ injected as a bolus in a representative 15-week old lamb. Plasma $\mathrm{GH}$ levels rose during the first $\mathrm{min}$ and were maximum $(130 \mathrm{ng} / \mathrm{ml}$ in this case) $1-4$ min after the injection of GRF. Secondary peaks of $\mathrm{GH}$ were observed during the $30 \mathrm{~min}$ following the injection after which plasma $\mathrm{GH}$ returned to basal levels. The multiphasic nature of the $\mathrm{GH}$ peak cannot be seen and the highest plasma $\mathrm{GH}$ levels were not measured when samples were taken every $10 \mathrm{~min}$ (fig. 1).

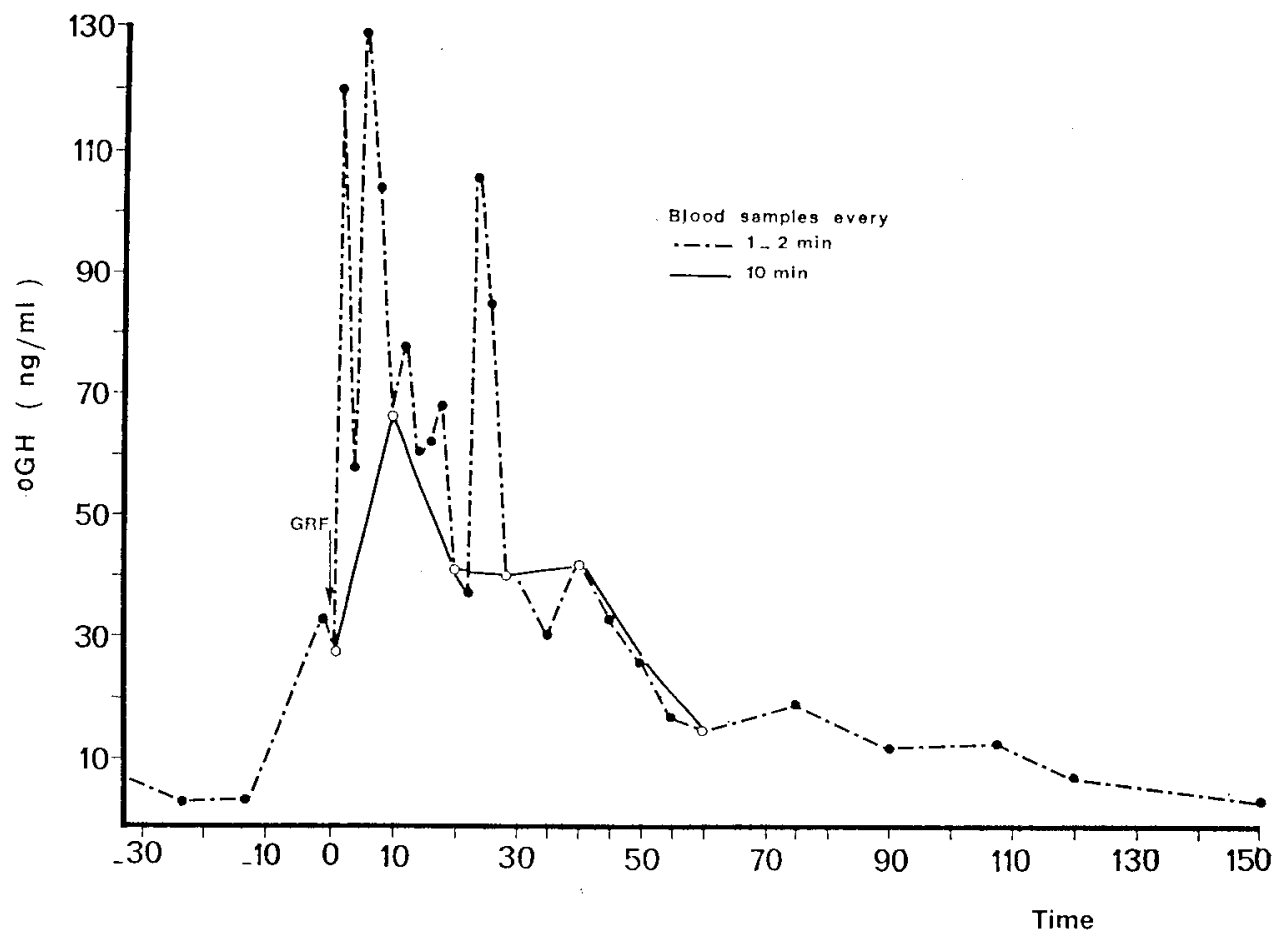

FIG. 1. - Kinetics of plasma GH levels in a 15-week old lamb given a single iv bolus of GRF 1-44 $(2 \mu \mathrm{g} / \mathrm{kg})$. The arrow indicates when GRF was administered. Representation of the same $\mathrm{GH}$ secretory profile but using $1-2 \mathrm{~min}(---)$ or $10 \mathrm{~min}(-)$ blood sampling intervals.

Figure 2 shows the $\mathrm{GH}$ response to GRF $1-44(0.1 \mu \mathrm{g} / \mathrm{kg})$ of four weaned lambs injected randomly at different times during their normal endogenous patterns of $\mathrm{GH}$ secretion. Using this lower dose, the amplitude of the $\mathrm{GH}$ peak subsequent to GRF injection was similar to spontaneous peaks and was only biphasic : the first occurred 3-9 $\mathrm{min}$ and the second 9-15 min after the injection of GRF, the two peaks being separated by 6-9 min. Plasma $\mathrm{GH}$ levels returned to basal concentrations within $30 \mathrm{~min}$ (fig. $2 \mathrm{~b}, \mathrm{c}$ ) except when a spontaneous peak of $\mathrm{GH}$ followed the GRF-induced one (fig. 2a). The lambs were responsive to GRF even when a spontaneous peak of $\mathrm{GH}$ had occurred just prior to (fig. $2 \mathrm{c}$ ) or during 


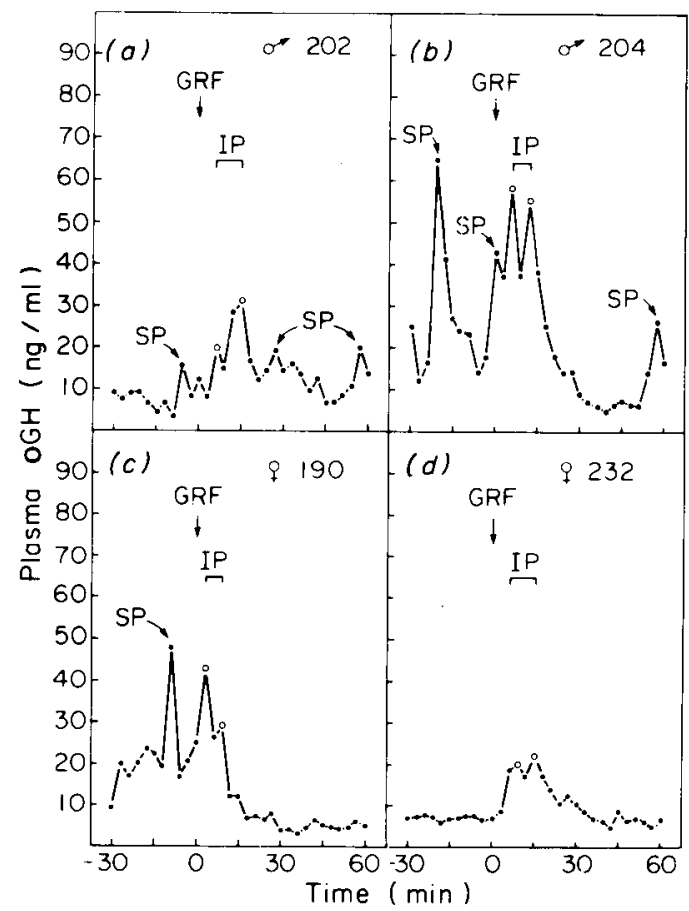

FIG. 2. - GH response in male and female weaned lambs (14-15 week old) given a single iv bolus of GRF $1.44(0.1 \mu \mathrm{g} / \mathrm{kg})$. Blood was sampled every $3 \mathrm{~min}$. The animals depicted were chosen because they best represented various endogenous GH secretory patterns, the timing when GRF was injected and responsiveness to GRF. Arrows indicate GRF injections at zero time. SP : spontaneous peak; IP : GRF-induced peak.

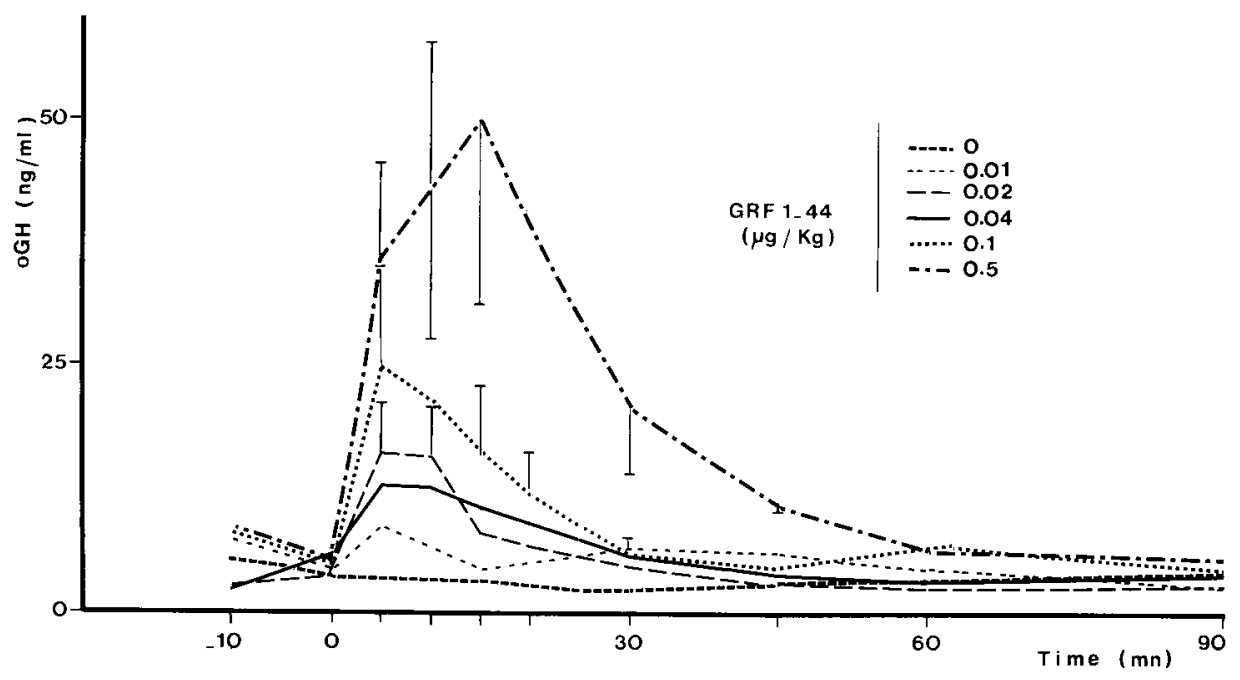

FIG. 3. - GH dose-response in suckling male lambs (5-6 week old) given single iv bolus injections of GRF $1.44(0-0.5 \mu \mathrm{g} / \mathrm{kg} ; 0-100$ pmole $/ \mathrm{kg})$. GRF was injected at zero time. Mean $\pm \mathrm{SEM}$ ( $n=5)$. 
the injection (fig. 2b). The amplitude of $\mathrm{GH}$ response to GRF injection was greater in lambs having higher spontaneous $\mathrm{GH}$ peaks than in those having fewer $\mathrm{GH}$ peaks and of lower amplitude (fig. 2b, c vs fig. 2a, d). No differences were observed between males and females, each sex demonstrating wide variations in spontaneous or GRF-induced secretory patterns of $\mathrm{GH}$.

Figure 3 shows the effects of increasing doses of GRF 1-44 on GH release in suckling lambs. Manipulation of the animals and injection of the vehicle alone did not produce any $\mathrm{GH}$ release. Few lambs responded to a dose of $0.01 \mu \mathrm{g} / \mathrm{kg}$ (2 pmoles $/ \mathrm{kg}$ ) of GRF, but all responded to higher doses in a dose-dependent manner. When GRF was given at a dose of $0.5 \mu \mathrm{g} / \mathrm{kg}$ (100 pmoles $/ \mathrm{kg}$ ), the amplitude of the $\mathrm{GH}$ peak was $50 \pm 19 \mathrm{ng} / \mathrm{ml}(\mathrm{m} \pm \mathrm{SEM}$ ) and the subsequent return to basal levels occurred 45 to $60 \mathrm{~min}$ after the injection. We observed that the animals which responded to the dose of $0.01 \mu \mathrm{g} / \mathrm{kg}$, responded the best to the higher doses.

The variations with time of GH response to GRF 1-44 and GRF 1-29 10.75 nmole $/ \mathrm{kg}$ l injected twice daily for 21 days in newborn lambs is depicted in figure 4. Basal plasma $\mathrm{GH}$ levels in controls varied between 2.3 and $12.4 \mathrm{ng} / \mathrm{ml}$ but did not change significantly during the course of the experiment. Plasma $\mathrm{GH}$ levels reached $68.2 \pm 19.0$ and $43.2 \pm 10.5 \mathrm{ng} / \mathrm{ml}$ on the first day of treatment (d1) after injection of GRF 1-29 and GRF 1-44, respectively. These levels increased
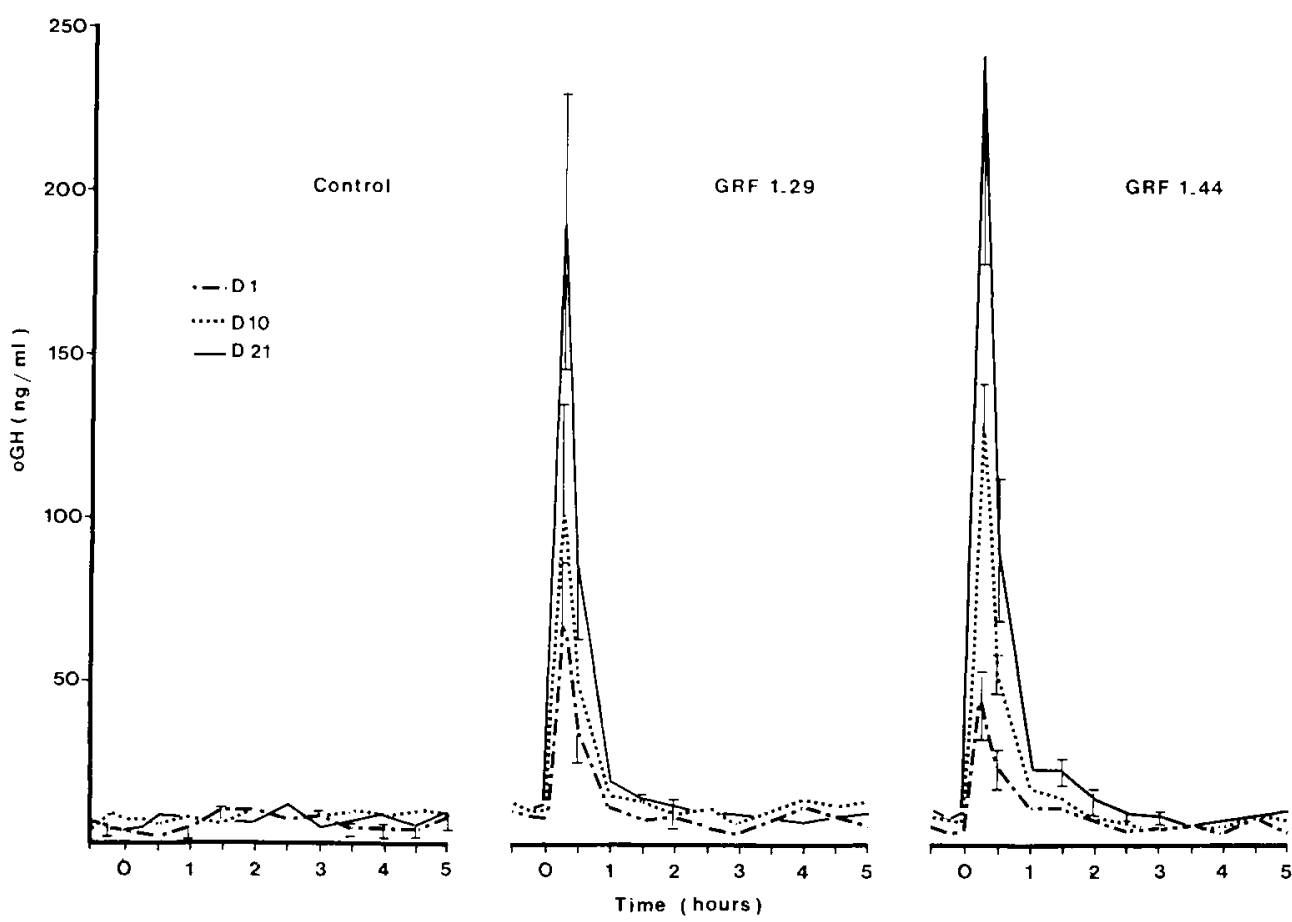

FIG. 4. - GH response to GRF at days 1, 10 and 21 in newborn male lambs that received a $\mathrm{SC}$ bolus injection of GRF 1-44 and GRF $1-29(0.75 \mathrm{nmole} / \mathrm{kg})$ twice daily for 21 days. Every day, GRF was administered at $8 \mathrm{a} . \mathrm{m}$. and $8 \mathrm{p} . \mathrm{m}$. and blood samples were drawn beginning $30 \mathrm{~min}$ before the $8 \mathrm{a} \cdot \mathrm{m}$. injection. Controls received the vehicle only. Mean $\pm \operatorname{SEM}(\mathrm{n}=5)$. 
to $100.0 \pm 35.4$ and $127.4 \pm 14.1 \mathrm{ng} / \mathrm{ml}$ on day 10 and to $188.4 \pm 41.6$ and $241.5 \pm 63.2 \mathrm{ng} / \mathrm{ml}$ on day 21, following GRF 1-29 and GRF 1-44 injection, respectively. The area under the curve that was plotted for GH concentration against time, increased significantly $(p<0.02$ ) from $d 1$ to $d 21$ for both GRF 1-29 and GRF 1-44 groups (table 1). There was no difference between GH response to GRF 1-29 and GRF 1-44 at any stage of treatment.

TABLE 1

Effect of a chronic treatment with GRF 1-44 and GRF 1-29 on GH response in lambs.

\begin{tabular}{lccc}
\hline Days & Control & GRF 1-44 & GRF 1-29 \\
\hline D 1 & $5.9 \pm 1.2$ & $16.2 \pm 3.0$ & $21.3 \pm 5.3$ \\
D 10 & $7.6 \pm 0.8$ & $34.6 \pm 4.3^{*}$ & $29.9 \pm 7.7$ \\
D 21 & $7.7 \pm 0.8$ & $61.1 \pm 13.8^{* *}$ & $48.8 \pm 7.1^{* *}$ \\
\hline
\end{tabular}

Data are expressed as $\mathrm{ng} \cdot \mathrm{h} . \mathrm{ml}^{-1}$. They were obtained by measuring the area under the line that was plotted for $\mathrm{GH}$ concentration against time after GRF injection. Results, given as mean \pm SEM $(n=5)$, were statistically analysed by analysis of variance (ANOVA) followed by Duncan's multiple range test.

Significantly different from controls : ${ }^{*} p<0.01 ;{ }^{*} p<0.02$.

\section{Discussion.}

The goals of this study were to examine whether lambs taken at two different postnatal stages, when $\mathrm{GH}$ secretory patterns were markedly different, would respond to GRF action. In addition, we have shown that GRF 1-44 and GRF 1-29 are equipotent stimulators of GH release. In fact, every GRF analog greater than the 1-27 sequence has been found to be equipotent to GRF 1-44 (Wehrenberg et al., 1983 ; Losa et al., 1984 ; Hart et al., 1985).

The typical response for both of the age group studied is that plasma $\mathrm{GH}$ concentrations reach maximum levels during the first minute which follows GRF injection. They remain elevated for approximately $30 \mathrm{~min}$ then decrease to basal levels. The pattern of $\mathrm{GH}$ secretion is multiphasic : when the animals received a high dose of GRF $(2 \mu \mathrm{g} / \mathrm{kg})$, we consistently observed 4-6 episodes of GH secretion; the number of secretory episodes tended to decrease with lower doses of GRF. Since GRF levels have been found to decrease in the circulation after an equilibration phase of $8 \mathrm{~min}$ (Frohman et al., 1984), the amount of exogenous GRF injected may have been enough to restimulate the pituitary gland several times. Because we saw several episodes of $\mathrm{GH}$ secretion and not one single prolonged response, this would suggest that the pituitary is not constantly responsive to GRF.

A biphasic pattern of $\mathrm{GH}$ secretion following GRF administration has been reported previously in men (Vance et al., 1984) and steers (Moseley et al., 1984), although the two peaks of $\mathrm{GH}$ were separated by about 2 hours. Because in this experiment the interval between the different peaks is only a few minutes, it is obvious that we are describing a different phenomenon. In the lamb, endogenous 
$\mathrm{GH}$ peaks have been described previously as monophasic (Davis et al., 1977). However, our use of more frequent blood sampling periods has allowed us to observe multiphasic episodic secretory peaks. Using the same technique, Laurentie et al. (1987) described the same phenomenon during the nycthemeral rhythm of GH secretion in ruminant lambs.

In weaned lambs, the $\mathrm{GH}$ response to exogenous GRF $(0.1 \mu \mathrm{g} / \mathrm{kg})$ had the same amplitude and duration as spontaneous peaks of $\mathrm{GH}$. The presence of a spontaneous pulse of $\mathrm{GH}$ just before or at the time of an injection of GRF did not seem to impair pituitary responsiveness. Likewise, the induction of a $\mathrm{GH}$ peak of physiological amplitude with GRF did not prevent the release of a spontaneous pulse within the next $60 \mathrm{~min}$. Thus, it appears that spontaneous and GRF-induced secretory episodes do not interfere with each other and that induction of a $\mathrm{GH}$ pulse does not disturb the endogenous rhythm of $\mathrm{GH}$ secretion over a period of at least one hour.

The animals with spontaneous $\mathrm{GH}$ peaks of higher amplitude responded best to GRF. Inversely, those which had spontaneous peaks of low amplitude responded to GRF with $\mathrm{GH}$ peaks of low amplitude. This suggests that some lambs are less responsive to GRF, whether it is exogenous or endogenous. However, we do not know why there was a so much variability between animals since they were apparently under the same environmental and physiological conditions.

As reported in other species, there is a dose-response effect of GRF on $\mathrm{GH}$ secretion in sheep. When injected subcutaneously (data not shown), there is also a dose-response effect but in a range of $2-20 \mu \mathrm{g} / \mathrm{kg}$. This is consistent with results obtained in men (Sassolas et al., 1985 ; Evans et al., 1985). When injected intravenously, the doses of GRF required to stimulate $\mathrm{GH}$ release are 10 to 100 times lower than subcutaneously. We find that the threshold of responsitivy to iv injections of GRF is between 0.01 and $0.02 \mu \mathrm{g} / \mathrm{kg}$ in suckling lambs but about $0.04 \mu \mathrm{g} / \mathrm{kg}$ in weaned lambs (M. Duclos, personnal communication). This agrees with a previous report that $\mathrm{GH}$ response and sensitivity to GRF action decrease with advancing age in ruminants (Johke et al., 1984). Using the same hGRF 1-44 (SANOFI), Boissel et al. (1986) found that the lowest effective iv dose was between 0.03 and $0.07 \mu \mathrm{g} / \mathrm{kg}$ in healthy adult men. Similar results have also been reported in steers (Moseley et al., 1984). In all of the species cited above, including lambs, the maximal effective dose of GRF is $0.5-1 \mu \mathrm{g} / \mathrm{kg}$. Similarities anong species concerning GRF dose-response effect have been confirmed in pituitary cell cultures (Law et al., 1984 ; Blanchard et al., 1987 ; Brazeau et al., 1982).

Finally, the most important difference between lambs and other species concerns the duration of the GH peak. In lambs, it never lasts longer than 1 hour, whatever the dose or the route of administration, while in men it may last 2 or 3 hours (Sassolas et al., 1985). In addition, we do not observe the rebound described in bovines (Moseley et al., 1984. McCutcheon et al., 1984).

The significant increase of $\mathrm{GH}$ response to GRF during the course of a chronic treatment was unexpected. The reasons for such an increased responsivity of the animals are not understood. Pastoureau et al. (1987) have recently reported an increase in plasma somatomedin- $C$ levels in hypotrophic lambs after 45 days of a comparable treatment. Therefore, the increased $\mathrm{GH}$ response in lambs chroni- 
cally treated with GRF may represent a significant effect of the releasing factor rather than a physiological event. This study demonstrates that suckling lambs are extremely responsive to GRF action. Thus, it is likely that the perinatal decrease in plasma GH levels in sheep is due to very low GRF secretion rather than to a refractory or inhibitory mechanism.

$12^{e}$ Réunion du groupe Développement INRA Montpellier, 28-30 mai 1986.

Acknowledgments. - This research was supported by SANOFI (grant $n^{\circ} 9532 \mathrm{~B}$ ). We thank the NIADDK for the supply of oGH RIA kit. We are grateful to Dr. Cynthia G. Goodyer for her helpful criticism and for reviewing the English.

Résumé. Caractéristiques de la réponse de la GH à l'administration de GRF chez l'agneau.

Nous avons étudié l'effet de l'administration de GRF 1-44 ou de GRF 1-29 chez des agneaux pris à deux stades physiologiques différents et ayant des profils de sécrétion de la GH différents : des agneaux allaités (âgés de 5-6 semaines) ne présentant pas de décharges épisodiques de la GH (niveaux de base : $5-10 \mathrm{ng} / \mathrm{ml}$ ) et des agneaux sevrés (âgés de 14-15 semaines) qui sécrètent la GH par épisodes (amplitude des pics : 15-65 ng/ml).

L'injection de GRF par voie iv stimule instantanément la sécrétion de la GH. Dans chaque cas, la GH plasmatique atteint son niveau maximum 1-4 min après l'injection de GRF. Le pic secrétoire est multiphasique et dure $30-60 \mathrm{~min}$. L'administration de GRF $(0.1 \mu \mathrm{g} / \mathrm{kg})$ chez l'agneau sevré induit des pics de GH dont l'amplitude et la durée sont comparables à celles des pics spontanés. L'induction d'un pic de GH par le GRF se produit même lorsque l'injection du GRF est pratiquée après ou pendant un pic spontané de GH. Inversement, on observe des pics spontanés de GH pendant I'heure qui suit l'induction d'un pic de GH par le GRF.

Chez l'agneau allaité, l'injection de GRF par voie intraveineuse dans une gamme allant de 0.01 à $0.5 \mu \mathrm{g} / \mathrm{kg}$ (2 à $100 \mathrm{pmoles} / \mathrm{kg}$ ) stimule la sécrétion de la $\mathrm{GH}$ de façon dépendante de la dose injecteee.

La réponse à l'administration biquotidienne de 750 pmoles/ $\mathrm{kg}$ de GRF 1-44 ou de GRF 1-29 pendant 21 jours chez l'agneau nouveau-né augmente significativement ( $p<0.001$ ) au cours du traitement. En revanche les réponses au GRF 1-44 et au GRF 1-29 sont identiques.

Ces résultats indiquent que l'agneau est extrêmement sensible au GRF que ce solt avant ou après le sevrage et qu'il n'y a pas de désensibilisation apparente de l'hypophyse après une administration aiguë ou chronique de GRF.

\section{Références}

BASSETT J. M., ALEXANDER G., 1971. Insulin, growth hormone and corticosteroids in neonatal lambs. Biol. Neonate, 17, 112-125.

BLANCHARD M. M., GOODYER C. G., CHARRIER J., DULOR J. P., BARENTON B., 1987. Effects of hypothalamic hormones (GRF, TRH, somatostatin) and insulin like-growth factor $I$ on growth hormone secretion from prepubertal male lamb pituitary cultures. Reprod. Nutr. Dévelop., 27, 471-480.

BOISSEL J. P., COHEN R., BIOT-LAPORTE S., CLAUSTRAT B., RENARD H., OLIVIER M., SASSOLAS G., 1986. Synthetic human growth hormone-releasing factor (h-GRF-1-44-NH2) dose response effect on growth hormone and prolactin secretion in healthy adult men. Eur. J. Pharmacol., 29, 609-614.

BRAZEAU P., LING N., BÖHLEN P., ESCH F., YING S., GUILLEMIN R., 1982. Growth hormonereleasing factor, somatocrinin, releases pituitary growth hromone in vitro. Proc. nat. Acad. Sci., 79, 7909-7913. 
CHARRIER J., 1973. Evolution foetale et postnatale du contenu en hormone de croissance de l'hypophyse ovine. Ann. Biol. anim. Bioch. Biophys., 13, 155-163.

DAVIS S. L., ANFINSON M., 1975. Dose-response influence of prostaglandin E1 and somatostatin on plasma levels of growth hormone, prolactin and thyrotropin in sheep. J. anim. Sci., 41, 172-177.

DAVIS S. L., OHLSON D. L., KLINDT J., ANFINSON M. S., 1977. Episodic growth hormone secretory patterns in sheep : relationship to gonadal steroid hormones. Am. J. Physiol., 233, E519-E523.

EVANS W. S., VANCE M. L., KAISER D. L., SELLERS R. P., BORGES J. L., DOWNS T. R., FROHMAN L. A., RIVIER J., VALE W., THORNER M. O., 1985. Effects of intravenous, subcutaneous and intranasal administration of growth hormone (GH)-releasing hormone-40 on serum $\mathrm{GH}$ concentrations in normal men. J. clin. Endocrinol. Metab., 61, 846-850.

FROHMAN L. A., THOMINET J. L., WEBB C. B., VANCE M. L., UDERMAN H., RIVIER J., VALE W., THORNER M. O., 1984. Metabolic clearance and plasma disappearance rates of human pancreatic tumor growth hormone-releasing factor in man. J. clin. Invest., 73, 1304-1311.

GLUCKMAN P. D., MUELLER P. L., KAPLAN S. L., RUdOLPH A. M., GRUMBACH M. M., 1979a. Hormone ontogeny in the ovine fetus. I. Circulating growth hormone in mid and late gestation. Endocrinology, 104, 162-168.

GLUCKMAN P. D., MUELLER P. L., KAPLAN S. L., RUDOLPH A. M., GRUMBACH M. M., $1979 b$. Hormone ontogeny in the ovine fetus. III. The effect of exogenous somatostatin. Endocrinology, 104, 974-978.

GUILLEMIN R., BRAZEAU P., BÖHLEN P., ESCH F., LING N., WEHRENBERG W. B., 1982. Growth Hormone-Releasing Factor from a human pancreatic tumor that caused acromegaly. Science, 218, 585-587.

GUILLEMIN R., BRAZEAU P., BÖHLEN P., ESCH F., LING N., WEHRENBERG W. B., BLOCH B., MOUGIN C., ZEYTIN F., BAIRD A., 1984. Somatocrinin, the growth hormone releasing factor. Rec. Progr. Horm. Res., 40, 233-299.

HART I. C., CHADWICK P. M. E., COERT A., JAMES S., SIMMONDS A. D., 1985. Effect of different growth hormone-releasing factors on the concentrations of growth hormone, insulin and metabolites in the plasma of sheep maintained in positive and negative energy balance. J. Endocr., 105, 113-119.

HODATE K., JOHKE T., KAWABATA A., FUSE H., OHASHI S., SHIRAKI M., SAWANO S., 1984. Growth hormone-releasing factor effect on secretion of growth hormone in ruminants. Nat. Inst. anim. Ind., 42, 41-43.

JOHKE T., HODATE K., OHASHI S., SHIRAKI M., SAWANO S., 1984. Growth hormone response to human pancreatic growth hormone-releasing factor in cattle. Endocrinol. japon., 31, $55-61$.

KRAFT L. A., BAKER P. K., RICKS C. A., LANCE V. A., MURPHY W. A., COY D. H., 1985. Stimulation of growth hormone release in anesthetized and conscious pigs by synthetic human pancreatic growth hormone-releasing factor [hpGRF(1-29)-NH2]. Dom. anim. Endocrinol., 2, 133-139.

LAURENTIE M. P., DUCLOS M., TOUTAIN P. L., CHARRIER J., BLANCHARD M., DULOR J. P., MARNET P. G., BARENTON B., 1987. Secretory profiles and production rate of growth hormone in ruminant lambs. Reprod. Nutr. Dévelop., 27, 525-532.

LAW G. J., RAY K. P., WALLIS M., 1984. Effects of growth hormone-releasing factor, somatostatin and dopamine on growth hormone and prolactin secretion from cultured ovine pituitary celis. FEBS Letters, 166, 189-193.

LING N., ESCH F., BÖHLEN P., BRAZEAU P., WEHRENBERB W. B., GUILLEMIN R., 1984. Isolation, primary structure and synthesis of human hypothalamic somatrocrinin : growth hormone-releasing factor. Proc. nat. Acad. Sci., 81, 4302-4306

LOSA M., SCHOPOHL J., MULLER O. A., Von WERDER K., 1984. Stimulation of Growth hormone secretion with human growth hormone-releasing factors (GRF 1-44, GRF 1-40, GRF 1-29) in normal subjects. Klin. Wochenschr., 62, 1140-1143.

McCUTCHEON S. N., BAUMAN D. E., MURPHY W. A., LANCE V. A., COY D. H., 1984. Effect of synthetic human pancreatic growth hormone-releasing factors on plasma growth hormone concentrations in lactating-cows. J. Dairy Sci., 67, 2881-2886. 
MOSELEY W. M., KRABILL L. F., FRIEDMAN A. R., OLSEN R. F., 1984. Growth Hormone response of steers injected with synthetic human pancreatic growth hormone-releasing factors. J. anim. Sci., 58, 430-435.

OHMURA E., JANSEN A., CHERNICK V., WINTER J., FRIESEN H. J., RIVIER J., VALE W., 1984. Human pancreatic growth hormone-releasing factor (hpGRF 1-40) stimulates $\mathrm{GH}$ release in the ovine fetus. Endocrinology, 114, 299-301.

PASTOUREAU P., BARENTON B., BLANCHARD M., CHARRIER J., DULOR J. P., THÉRIEZ M., 1987. Effects of a long term treatment with growth hormone releasing hormone (GRF) on growth hormone and somatomedin $\mathrm{C}$ blood levels, on skeletal growth, animal performances and food intake in normal and low birth-weight lambs. Reprod. Nutr. Dévelop., (soumis).

RIVIER J., SPIESS J., THORNER M., VALE W., 1982. Characterization of a Growth HormoneReleasing Factor from a human pancreatic islet tumor. Nature, 300, 276-278.

SASSOLAS G., BIOT-LAPORTE S., COHEN R., CHARFI A. E., FERRY S., BORSON F., 1985. Effects on growth hormone secretion following intravenous and subcutaneous injections of growth hormone-releasing factor (hGRF-44-NH2): comparison of immunoreactive plasma GRF levels. Clin. Endocrinol., 22, 645-653.

SCANES C. G., CARSIA R. V., LAUTERIO T. J., HUYBRECHTS L., RIVIER J., VALE W., 1984. Synthetic human pancreatic growth hormone-releasing factor (GRF) stimulates growth hormone secretion in domestic fowl /Gal/us Domesticus/. Life Sci., 34, 1127-1134.

THORNER M. O., SPIESS J., VANCE M. L., ROGOL A. D., KAISER D. L., WEBSTER J. D., RIVIER J., BORGES J. L., BLOOM S. R., CRONIN M. J., EVANS W. S., MAC LEOD R. M., VALE W., 1983. Human pancreatic growth hormone-releasing factor selectively stimulates growth hormone secretion in man. Lancet, 1, 24-28.

VANCE M. L., BORGES J. - L. C., KAISER D. L., EVANS W. S., FURLANETTO R., THOMINET J. L., FROHMAN L. A., ROGOL A. D., MAC LEOD R. M., BLOOM S., RIVIER J., VALE W., THORNER M. O., 1984. Human pancreatic tumor growth hormone-releasing factor : doseresponse relationships in normal man. J. clin. Endocrinol. Metab., 58, 838-844.

WEHRENBERG W. B., LING N., 1983. In vivo biological potency of rat and human growth hormonereleasing factor and fragments of human growth hormone-releasing factor. Biochem. Biophys. Res. Commun., 115, 525-530.

WEHRENBERG W. B., LING N., BRAZEAU P., ESCH F., BÖHLEN P., BAIRD A., YING S., GUILLEMIN R., 1982. Somatocrinin, growth hormone-releasing factor, stimulates growth hormone in anesthetized rats. Biochem. Biophys. Res. Commun., 109, 382-387. 